\title{
LA TRADUCCIÓN FEMINISTA INTRALINGÜÍSTICA \\ EN THE WILD GIRL ${ }^{1}$ \\ Bárbara Cerrato Rodriguez. \\ Universidad de Salamanca
}

\section{ABSTRACT}

The present paper starts from the concept of translation as rewriting -a line of research which originated from the post-structuralist theories of translation and history and developed by authors such as Baker, Bassnett, Bielsa, Hernández Guerrero, Johnston, Lefevere, Tymoczko, Valdeón, etc. and addresses the novel The Wild Girl, written by Michèle Roberts.

This novel is a feminist rewriting that combines the feminist critic of myths and the revisionist creation of myths in order to subvert four Christian myths, and reveal the surreptitious and symbolic violence exercised against women by the patriarchy.

KEYWORDS: Translation as rewriting, The Wild Girl, Feminist rew riting, Michèle Roberts

\section{RESUMEN}

En el presente artículo partimos del concepto de traducción como reescritura -una línea de investigación que surgió a partir de las teorías post-estructuralistas de la traducción y la historia, y que ha sido desarrollada por autores como Baker, Bassnett, Bielsa, Hernández Guerrero, Johnston, Lefevere, Tymoczko, Valdeón, etc- y aborda la novela The Wild Girl, de Michèle Roberts.

Esta novela es una reescritura feminista que combina la crítica feminista de mitos y la creación revisionista de mitos para subvertir cuatro mitos cristianos, y sacar a la luz la violencia subrepticia y simbólica que ejerce el patriarcado contra la mujer.

PALABRAS CLAVE: Traducción como reescritura, The Wild Girl, Reescritura feminista, Michèle Roberts.

FECHA DE RECEPCIÓN: 16/03/2017

FECHA DE ACEPTACIÓN: 30/06/2016

PÁGINAS: 95-105

\footnotetext{
${ }^{1}$ El presente artículo se inscribe en el proyecto de investigación "Violencia simbólica y traducción: retos en la representación de identidades fragmentadas en la sociedad global” (FFI2015-66516-P), financiado por el Ministerio de Economía y Competitividad del Gobierno de España.
} 


\section{INTRODUCCIÓN}

Si algo tienen los Estudios de Traducción de cautivadores es que se tratan de una disciplina que refleja a la perfección los cambios sociales, políticos y culturales de las lenguas desde y a las que se traduce. Como bien es sabido, esta idea de la traducción como espejo de los devenires sociales de cada época hizo posible que, principalmente a partir de los años ochenta, algunos teóricos incorporaran otros conceptos como manipulación (Hermans, 1985), ideología y cultura (Bassnett y Lefevere, 1990) a los Estudios de Traducción. Del mismo modo, se añadieron otros conceptos desde la sociología, como los de violencia simbólica (Bourdieu [1998] 2015) y microfisica del poder (Foucault, 1985). El Poder resulta especialmente significativo para los Estudios de Traducción en tanto que, tras el giro cultural de la traducción, tuvo lugar el giro de poder, que sostenía que el discurso y la traducción son un juego de Poder en el que la ideología dominante, junto con su discurso oficial, ocupa la cúspide de la pirámide (Tymoczko y Gentzler 2002).

Asimismo, los movimientos sociales que se estaban desarrollando durante la década de los ochenta, principalmente en Francia y Estados Unidos, provocaron que los movimientos feministas influyeran también en la traducción, lo que dio lugar a que un número de traductoras, sobre todo canadienses, se declararan abiertamente feministas -Susanne de Lotbinière-Harwood (1995), Barbara Godard (1990), Luise von Flotow (1991; 1997), Sherry Simon ([1996] 2010), Marlene Wildeman (1989), etc.-.

De este modo, el carácter novedoso del presente artículo estriba en la aplicación a un caso concreto, la novela feminista The Wild Girl ([1984] 2007), de la definición más abarcadora de la traducción que se reconoce en el concepto de reescritura, desarrollada por autores como Munday (2014), Bassnett (2011), Tymoczko (2007), Johnston (2013), Gentzler (2003), Vidal (2015) y Brems et al. (2014), entre otros.

Por consiguiente, hemos divido el presente artículo en tres partes: en la primera, nos referiremos brevemente al maridaje entre el feminismo y la traducción; en la segunda, esbozaremos esta nueva definición ligada al concepto de traducción; y finalmente, ya en la tercera parte, aplicaremos esta nueva definición mucho más amplia y abarcadora de la traducción a la novela feminista The Wild Girl[[1984] 2007), escrita por Michéle Roberts.

\section{EL MARIDAJE ENTRE EL FEMINISMO Y LA TRADUCCIÓN}

Tradicionalmente, la mujer y la traducción han ocupado una situación de inferioridad comparable. Tanto es así que la autoridad del texto original en detrimento de la traducción se ha equiparado con la situación de inferioridad que ha ocupado la mujer con respecto al hombre. De hecho, el texto origen se identifica con el varón, fuerte y generativo, y el texto meta, con la mujer, más débil y derivada (Simon [1996] 2010: 1). En vista de lo anterior, no debe sorprender entonces que las mujeres hayan recurrido a la traducción como vía de emancipación y consecución de la igualdad a lo largo de la Historia: de hecho, reformularon el concepto de fidelidad y lo aplicaron, ya no al autor ni al lector, sino, muy por el contrario, al proceso de redacción en sí, un proceso en el que intervienen tanto el autor como el traductor.

Sin embargo, parece evidente que reconsiderar la traducción supone ampliar la definición del sujeto traductor: de este modo, sólo cabe entenderla si se tiene en cuenta la identidad de los sujetos traductores y su responsabilidad como «signatarios» de documentos elaborados por dos autores (Simon [1996] 2010: 13). En definitiva, todo lo anterior refleja que se ponen en tela de juicio algunos aspectos como la autoridad y la agencia, puesto que «when meaning is no longer a hidden truth to be 'discovered', but a set of discursive conditions to be 're-created', thework of the translator acquires added dimensions» (ibid.): 
No final version of the texts is ever realizable. There are only approximations to be actualized within the conditions of different enunciative exchanges. As such, translation is concerned not with 'target languages' and the conditions of 'arrival' but with the ways of ordering relations between languages and cultures. Translationisan art of approach. (Godard, 1995: 81)

Las traductoras van tomando conciencia de su responsabilidad a la hora de re-crear el significado de un texto y la responsabilidad que trae consigo verterlo a otro idioma. En este sentido, cabría resaltar tres prácticas características del feminismo traductor: (1) supplementing ${ }^{2}$ (compensación), (2) prefacing ${ }^{3} \mathrm{y}$ footnoting 4 (prefacios y notas al pie), y (3) bijacking5 (secuestro, entiéndase, del texto) (von Flotow, 1997: 1415). A modo de ilustración de esta última estrategia, la más invasiva de todas ellas, podría servir la traducción de Susanne de Lotbinière-Harwood' ${ }^{6}$ de Lettresd'uneautre (1984), de Lise Gauvin. En ella, la traductora evita el masculino genérico feminizándolo y lo justifica en un buen número de notas a pie de página y enel prefacio:
Dear reader,
Just a few words to let you know that this translation is a rewriting in the feminine of what I originally read in French. I don't mean content. Lise Gauvin is a feminist, and so am I. But I am not her. She wrote in the generic masculine. My translation practice is a political activity aimed at making language speak for women. So my signature on a translation means: this translation has used every translation strategy to make the feminine visible in language. Because making the feminine visible in language means making women seen and heard in the real world. Which is what feminism is all about. (Gauvin 1989: 9)

En vista de lo anterior, es evidente que la traducción feminista supone ampliar y desarrollar la intención del texto original, pero no deformarla. Por esa razón, la mayoría de los ejemplos satisfactorios de estas prácticas feministas se han producido cuando existía, al menos, una cierta correspondencia entre el texto original y el proyecto de traducción (Simon [1996] 2010: 16). En vista de ello, cabe preguntarse si esta opción es más recomendable, a saber, que las traductoras feministas dediquen sus esfuerzos a textos que compartan su ideología.

Asimismo, parece que la traducción se ha considerado una vía para fomentar la creatividad, algo que sigue vigente en la actualidad. A principios de los años ochenta, en una de las primeras reflexiones al respecto, Carol Maier defiende que las traductoras «give voice, to make available texts that raise difficult questions and open perspectives» y sostiene, además, que las traductoras deberían dedicarse tanto a textos afines como contrarios, lo que fomentaríasu independencia y resistencia ante estas obras (Maier, 1985: 4). Por su parte, de Lotbinière-Harwood defiende lo contrario: expone que los tres años que dedicó a la traducción de la poesía de Francoeur la obligaron a «speak in the masculine [...] as if the only

\footnotetext{
2 Pese a que se trata de un proceso legítimo de traducción, un uso excesivo de esta técnica puede llegarse a tachar de exhibicionismo textual, pues normalmente se espera que la traducción sea un proceso fluido y transparente.

${ }^{3}$ Es una estrategia rutinaria en la traducción feminista y suele tener como meta resaltar la importancia de las estrategias traslativas.

${ }^{4}$ Como es evidente, las notas del traductor aportan más información, lo que hace que el texto sea más denso. No obstante, no dejan de ser, al mismo tiempo, un reflejo del contexto cultural en el que tiene lugar el texto. Más concretamente, en el caso de las traductoras feministas, suelen recu rrir a ellas para superar la barrera de la invisibilidad que ha ido aparejada tradicio nalmente al ejercicio de la traducción. Poreso, «[f]eminist influence on translation and translation studies is most readily visible in the metatexts -the statements, theoretical writings, prefaces and footnotes that have been added to work published since the late 1970s» (von Flotow 1997: 21-22 y 35).

${ }^{5}$ Es una estrategia en la que traductora aplica una estrategia feminizante, lo que suele ser verdaderamente controvertido.

${ }^{6}$ Esta traductora "offers no excuses or justifications for feminist intervention in texts, but an abundance of compelling reaso ns. De Lotbinière-Harwood openly practices feminist translation and dearly situates herself as a participant in the discourses of Quebec's experimental écriture au féminin, as politicized, feminist subject. For her, no act of writing or translation is neutral [...]" (von Flotow 1997: 27).
} 
speaking place available, and the only audience possible, weremale-bodied», lo que provocó que no volviera a traducir poesía compuesta por un varón (de Lotbinière-Harwood, 1995: 64)7.

A pesar de que la traducción se ha considerado una versión débil, degradada y dependiente de la autoría, como decíamos al principio, en algunas ocasiones también ha emergido como una sólida vía de expresión para la mujer, lo que les ha permitido participar del mundo de las letras y promover causas políticas (Simon [1996] 2010: 39). Si bien es verdad que también cabría argüir lo contrario:

[T] hat the persistent historical association between women and translation has also meant that women have been confined to a subordinate writing role, that they were "only" translators when they might have been enjoying the privileges of full authorship, "bearers of the word" [...] rather than creators. (Simon [1996] 2010: 39)

\section{3. ¿QUÉ SIGNIFICA TRADUCIR EN LA ACTUALIDAD?}

Hasta los setenta, «[t]he study of translation occupied a minor corner of applied linguistics, an even more minor corner of literary studies, and no position at all in the newly developing Cultural Studies» (Bassnett, 1998: 124). Más tarde, en 1972, Holmes presentó el ensayo «The Name and Nature of Translation Studies» que supuso el paso del prescriptivismo al descriptivismo y eleva la traducción al nivel de texto original porque entiende que quien recurre a ella lo hace porque, evidentemente, no puede acceder al original. Durante esta misma década, además, se produjo el giro pragmático «que, [...], favoreció una visión más holística e interdisciplinar de la traducción, una percepción más crítica y productiva del proceso traductor y sus resultados, y, por ende, impulsó el desarrollo de los Estudios de Traducción como disciplina independiente» (Snell-Hornby, en Ortega Arjonilla, 2007: 24).

Las décadas de los ochenta y los noventa del siglo XX supusieron la redefinición de la disciplina a partir de interpretaciones determinadas por la cultura y relacionadas con el Poder. Tanto es así que el postestructuralismo, de la mano de Derrida, Lyotards, Kristeva y Barthes, entre otros, establecía que la realidad es un artefacto simbólico confeccionado a partir de premisas ideológicas (Vidal, en prensa) y abordaba cuestiones como la asimetría cultural, la representación del Otro, el Poder occidental y su representación, la relación entre la producción del conocimiento y su transmisión y su consiguiente admisión por la cultura meta:

[S]ince translation provides the grounds for human communication but it is also a source of domination by shaping our understanding of reality, helping establish and maintain social hierarchies and mediating practices by connecting individuals to institutionalized hierarchies.(ibid.)

El Poder, un «proceso social» para Foucault, resulta especialmente significativo para nuestra disciplina, puesto que produce el conocimiento y pasa a formar parte de los Estudios de Traducción en la década de los ochenta, cuando la traducción abordaba cuestiones relacionadas con la ideología.Foucault relacionó por primera vez, en las décadas de los sesenta y los setenta, el lenguaje y el Poder (Foucault [1971] 1992: 19), lo que nos permite colegir que, dado que el lenguaje es una herramienta de Poder, también lo será la Traducción. Este mismo autor rechaza, además, la existencia de una organización piramidal opresora y la sustituye por su concepto de la microfísica, que explica la existencia múltiples focos de emisión de discursos cuya pretensión es convertirse en Verdades.Esta teoría recibió una gran acogida en nuestra disciplina, principalmente por parte de Lefevere y Bassnett ([1990] 1995) y Lefevere (1992). Por su parte, Bourdieu era partidario de entender el Poder como vía para re-

\footnotetext{
7 “De Lotbinière-Harwood's decision to translate only women authors from that point on may be decried as 'the paradox of censorship in the name of feminism' [...], analogous to the rejection suffered traditionally by women writers in patriarchy. For her, it is a question of self-preservation; and for readers it may be an indication of the extent to which the translator's female identity and feminist subjectivity enters into her work" (von Flotow 1997: 28)
} 
presentar la realidad y crear significados (1991; 1992): «and allconstruction of meaning implies acceptance of the power generating it» (Vidal, en prensa). De este modo, tiene lugar lo que Bourdieu denomina «el imperialismo del universal» (1992: 154), es decir, el hecho de que el Poder puede perpetuar o menoscabar el discurso que emana de las instituciones.

A translation stands in place of another entity and has authority to substitute for or act in place of that entity. [...] The definition of representation and the use of representation as a frame of reference for translation make manifest some of the reasons why translation itself is so powerful an act, why translations have played significant and transformative roles in many cultural contexts throughout history. The definition of representation illuminates why translations are constitutive of reality and why the process of translation is associated with textual manipulation. (Tymoczko, 2007: 112-113)

En el ámbito de la traducción, un buen número de autores - como Mona Baker, Theo Hermans, Edwin Gentzler, Lawrence Venut, Barbara Godard, Rosemary Arrojo, Jacques Derridà, Jeremy Munday, África Vidal, Roberto Valdeón, Rosario Martín Ruano, Homi Bhabha, Gayatri Spivak, Tejaswini Niranjana, Michael Cronin, etc.- han defendido que el traductor está influido por las relaciones de Poder existentes entre las culturas desde y a las que traduce. Poresemotivo, es preciso que el traductor se adentre «into the vagaries and vicissitudes of the exercise of power in a society, and what the exercise of power means in terms of the production of culture, of which the production of translations is a party (Lefevere y Bassnett [1990], 1995: 5). Lefevere aplicó la noción de Poder de Foucault para demostrar que ni escribir, ni traducir, son actos inocentes: «the study and practice of translation is inevitably an exploration of power relationships within textual practice that reflect power structures within the wider cultural context» (Bassnett, en Álvarez y Vidal, 1995: 21). En este contexto, se produjo el giro de poder (Tymoczko y Gentzler, 2002) que entendía que nuestra disciplina se basa en una toma de decisiones constante y deliberada en la que los traductores participan del Poder y contribuyen a crear el conocimiento y forjar una cultura.

En tanto que correlato de Poder, la Traducción a menudo se ha utilizado para poner en tela de juicio situaciones donde existen relaciones asimétricas de hegemonía y subordinación, como hicieran las traductoras feministasrebelándose contra un orden social, cultural y lingüístico androgénico y contra las funciones secundarias que se le atribuyen a la traducción con respecto del original.

[P]ara las feministas, la traducción es toda un arma política empleada para dar visibilidad a la mujer; también a la traducción, que frente al restringido papel que le otorga un orden cultural receloso de sus funciones explota su potencial creador y naturaleza productiva [...] (Martín Ruano en Ortega Arjonilla, 2007: 43)

Además, durante los ochenta y los noventa, la traducción continuó incorporando otros conceptos como cultura (Bassnett [1980] 2014), manipulación (Hermans, 1985), la idea del giro cultural (Lefevere y Bassnett [1990] 1995) y reescritura (Lefevere, 1992).

En definitiva, si algo ha quedado claro tras el giro cultural es que la traducción no es reproducción fiel ni tampoco neutral sino que implica un posicionamiento ideológico deliberado (Tymoczko, 2003) y una toma de decisiones constante (Tymoczko y Gentzler, 2002: xxi):

In this conflict-ridden and globalized world, translation is central to the ability of all parties to legitimize their version of events, especially in view of the fact that political and other types of conflict today are placed out in international arena and can no longer be resolved by appealing to local constituencies alone. (Baker 2006: 1)

\footnotetext{
8 Otros autoras que comparten esta idea son Godard (1990), Simon (1996), von Flotow (1991; 1997), Massardier-Kenney (1997) y Godayol (2005). 
Por lo tanto, puede que debamos cambiar nuestra cosmovisión y reconocer la existencia potencial y el valor de múltiples verdades (Baker 2006: 18-19).Parece evidente que traducir no es sustituir las palabras de una lengua por las de otra, pero tampoco puede ser una rendición ante el relativismo y un abandono ante el «todo vale». Definir la traducción es «un asunto serio» (Eco [2003] 2008: 31) porque traducimos continuamente, desde que nos levantamos hasta que nos acostamos (Duch 1998: 467):《[e]n cada momento, en cada acción que realizamos, activa o pasivamente, estamos traduciendo, y me parece apasionante entender ese verbo en gerundio. Como algo que está vivo, y que tiene un sentido muy amplio» (Vidal 2010: 20).

\section{LA TRADUCCIÓN FEMINISTA DE MICHÉLE ROBERTS EN THE WILD GIRL}

Partiendo de esta definición amplia y abarcadora de la traducción, Michèle Robertstraduce la historia y la tradición cristianas en la novela The Wild Girl([1984] 2007) en tanto que las reescribe en el más puro sentido de narración que desarrollara Hayden White (1987) para que se ajusten a su propósito: mejorar la situación de la mujer.

El personaje bíblico de María Magdalena, la protagonista de la novela, ha sido objeto de numerosas interpretaciones, y por consiguiente traducciones, tanto en el mundo de la literatura -como en El legado oculto de María Magdalena (2005)y Diario de María Magdalena (2011), entre otros muchos-, como en el de la música -como Una canción para la Magdalena, de Joaquín Sabina, y Judas, de Lady Gaga-. No obstante, por motivos de espacio, en este artículo nos centraremos únicamente en la traducción de cuatro mitos cristianos que presenta la novela The Wild Girl([1984] 2007) por sus vindicaciones feministas: la resurrección de Lázaro, la Virginidad de María, el Milagro de los Panes y los Peces, y la Resurrección de Jesús.

Antes de comenzar el análisis, es preciso señalar las motivaciones que llevaron a Roberts a escribir esta novela. Según afirma la autora, necesitaba averiguar por qué, según la Teología, las mujeres no podían disfrutar del sexo y ser santas al mismo tiempo: «whythemale-dominated Church Split women into holy sexless mothers and bad sexy whores» (ibid: n. p.). Asimismo, señala que otra de sus motivaciones fue intentar imaginar una cristiandad inspirada tanto por hombres como por mujeres: una religión basada en el amor, «rather than a religión of fear» (ibid.). De hecho, explica que María Magdalena se le apareció en sueños y que ello contribuyó a que se imaginara el evangelio que podría haber escrito esta santa.

These days, when fundamentalist versions of Christianity are once more on the rise, when political leaders use biblical imagery to excuse their crusades against other countries, Mary Magdalene remains, for me, a figure who challenges their narrow-minded certainties. (ibid.)

Además, Roberts afirma que ha decidido respetar la tradición vigente durante siglos en lo que respecta a este personaje bíblico y añade que los Evangelios Gnósticos de Nag Hammadi han sido una fuente de ideas significativa:

Medieval and later tradition in art, hagiography, legends, poems and plays collapses the figure of Mary Magdalene, briefly mentioned in the Gospels, into that of Mary of Bethany, the sister of Martha and Lazarus, and also in that of the sinful woman who anoints Christ. Although many modern scholars distinguish separate figures in the Gospel accounts, I have chosen to follow the tradition of centuries, the spinning of stories around a composite character.

One important source of ideas was the Nag Hammadi gospels [...]. I used the Nag Hammadi texts to help me imagine what an alternative version of Christianity might have been like. (Roberts [1984] 2007: n. p.) 
Como decíamos, The Wild Girl, narrada en primera persona, contiene la autobiografía, traducida y reescrita a partir de un enfoque feminista de María Magdalena, quien afirma que no quiere repetir las palabras de Jesús, sino que quiere dejar constancia de cómo recibió ella a Dios: «I pray that readers of this account will accept that now I am telling the truth, my truth, as fairly as I can» (ibid.: 70). Asimismo, admite que, al principio pensaba que escribir la verdad era sencillo, pero finalmente prueba no ser así: «[b]ut I have discovered over the last year that finding the truth in words is a struggle, and that recording it has increased my doubts and confusions rather than lessening them» (ibid:: 162).

Ahora que ya hemos repasado brevemente el punto de partida y la motivación de Roberts, procederemos a analizar la traducción de los cuatro mitos cristianos.

En primer lugar, empezaremos con la Resurrección de Lázaro, llevada a cabo por uno de los amigos de éste, Jesús, a quien María Magdalena describe como «quite ugly, with a linedface and a bignose, a lightly hunched back» (ibid:: 33). Jesús solía visitarlos acompañado de Juan y Simón Pedro, que desdeñaba a la Magdalena por su profesión de hetaira. No obstante, la traducción de esta santa que nos presenta Roberts no se avergüenza en absolutode elloy decide sacar provecho de sus atributos femeninos: «[b]ut it piqueted me, more, it angered me, his scorn for what I represented, and I fought back in the only ways I knew, pulling my hair forwards over my shoulders in the lamplight, letting him see the lift of my profile, of my breasts (ibid: 36). Al contrario que Simón Pedro, Jesús la respeta y la trata con amabilidad, y la Magdalena admite que se empieza a fraguar una amistad entre ambos, algo que consideraba imposible entre un hombre y una mujer. Señala también que Jesús «drewpeople to himself just as the sun drawsout moisture fromplants» (ibid: 36 ) y explica que, tras su partida, su hermano Lázaro cae enfermo. Para ella, se debe a que añoraba a Jesús y su compañía, y concluye que: «[he] was dying for love» (ibid:: 38). Jesús llega al tercer día y visita a María Magdalena en la casaque compartía con sus dos hermanos, Marta y Lázaro: "[h]e held me against him and I smelt his sweat and his hot skin. His tongue gently exploring my mouth was one of the sweetest and sharpest pleasures I have ever known, and he held me more tightly as he felt me opening to him» (ibid:: 41).Después, Jesús se presenta en la tumba a donde habían llevado a Lázaro y le ordena que salga. Es decir, la autora traduce y reescribe la muerte y el milagro, y nos lo presenta como una especie de depresión grave en la que se ve sumido Lázaro tras la marcha del Mesías y de la que se recupera con las palabras de éste. Tras la resurrección de Lázaro, la Magdalena le lava los pies a Jesús con su pelo, «the first service of love I had ver perfomed for a man» (ibid.), y al acabar le besa. Esa misma noche, tiene lugar el primer encuentro sexual entre ambos, otra subversión significativa de la Teología.

En segundo lugar, Roberts traduce y reinterpreta la historiografía oficial acerca de la pureza de la Virgen María. De este modo, explica que el embarazo tuvo lugar cuando ésta estaba prometida con José pero no habían contraído matrimonio, es decir, lo que, según Roberts, se considera ser virgen en hebreo: «[s]he told me her story then, how, when she was betrothed to Joseph but not yet married, a virgin according to our Hebrew way of naming, she was discovered to be pregnant, and how all the people of her village whispered against her and vilified hen» (ibid:: 66).

En tercer lugar, Roberts también traduce el Milagro de los Panes y los Peces de la siguiente manera:

People called it miracle afterwards. I called it good housewifery. I daresay we meant the same thing. Within minutes Martha had the disciples organized, sending us hither and thither amongst the crowd, and within what seemed only a short further space of time we were all sitting down to feast on bread and dried fish and fruit that people ran back to their homes to fetch and then to distribute. (ibid:: 76)

Parece evidente aquí que Roberts se olvida, al menos en parte, de la figura de Jesús y elogia el buen hacer femenino que permite repartir equitativamente la comida de la que disponen entre todos los asistentes a las enseñanzas de Jesús. 
En cuarto lugar, la autora subvierte la Resurrección del Señor. Tras el entierro de Jesús, la Magdalena quiere velar su cuerpo, pero la Madre del Señor ${ }^{9}$ le indica que vuelva a casa con ellos para evitar que los soldados, ya ebrios, abusen de ella. La mañana del tercer día, María Magdalena se mantiene en vela para evitar las pesadillas que la habían acechado durante las dos noches anteriores y decide visitar el sepulcro. Al llegar, lo encuentra abierto y vacío, y sin rastro de los soldados que lo custodiaban. Es entonces cuando Jesús, ya resucitado, se aparece por primera vez, precisamente ante una mujer que había sido objeto de tantas burlas, y ella se dirige a él como «rabboni ${ }^{10}$ ». Éste le ordena que no le toque porque ya no se encuentra en su cuerpo como cuando ambos se amaban en el lecho y le pide que transmita una serie de mensajes al resto. A modo de ilustración, cabría destacar el siguiente mensaje, pues podría considerarse una oda al amor libre, un tanto contrario al que parece promulgar la Iglesia en la actualidad:

How else can we know God except through the fullest knowledge of our humanity? This is why we must revere the turning points in our journey through life: we must celebrate the birth of children; their passage, through the signs given by the body, into adulthood; their joining one another in love and in bodily union; their flourishing and their maturity; their passage into wisdom and old age; their production of children; their meeting, terrible as it is, with death. (ibid:: 109)

Asimismo, Roberts reescribe, desde un punto de vista evidentemente sesgado, la resurrección consignada en las Sagradas Escrituras y la considera la unión con nuestro ser más profundo:

What is this rebirth? How is it to be achieved? The image of this rebirth is a marriage, as I have old you before, the marriage between the inner woman and the inner man. You must go down deep, down in the marriage chamber, and find the other part of yourselft that has been lost and missing for so long. Those who are reunited in the marriage chamber will be never be separated again. This is the restoration. This is the resurrection. (ibid.: 111)

Además, y a modo de clara vindicación feminista, la Magdalena transmite a los discípulos el mensaje que le había dado Jesús: la humanidad ha perdido el conocimiento de la Madre y, mientras siga siendo así, jamás se podrá llegar a Dios. Tanto es así que añade que se debe celebrar la unión del cuerpo y el espíritu que conforman un todo, porque eso es precisamente a lo que se refería Jesús en su última cena con: «he or she ${ }^{11}$ who shall no teat my flesh and drink my blood has not life» (ibid.). Por último, la Magdalena les transmite que, según las palabras del Salvador, carne debe entenderse como palabra y sangre, como Sophia, en el sentido de sabiduría. Mientras el resto de discípulos guarda riguroso silencio, Pedro sostiene que no cree que Jesús dijera jamás nada parecido y que la Magdalena miente: «[i]f he had [thought such things], we would have told them to uswhile he wasstillalive. Who ever heard such ridiculous teachings? Mary is raving. She has made them up» (ibid.: 111-112). Pese a que Marta defiende a su hermana María Magdalena, Pedro continua preguntando al resto»[w]ould the Lord really speak privately with a woman and not openly to us? Are we to turn about and all listen to her? Did he prefer her to us?» (ibid.: 112) y concluye así: «[y]ou are only a woman [...]. Youneed to rest, Mary» (ibid.). Es decir, una vez más parece que el hombre, en este caso los discípulos, es digno de mayor importancia que la mujer y, además, el hecho de que Pedro invite a la Magdalena a tomarse un descanso podría entenderse como que esta última es más débil. En este punto, interviene la Madre del Señor afirmando que la primera de las enseñanzas de su hijo era «brotherly and sisterly love between ourselves» (ibid:: 113),

\footnotetext{
${ }^{9}$ Michèle Roberts utiliza esta fórmula para referirse a la Virgen María. Cabría colegir que no se refiere a ella como Virgen porque reescribe el mito y lo deconstruye, eliminando de él todo rastro de alusión a la virginidad física.

${ }^{10}$ Se trata del título más elevado y honorífico que podían recibir los maestros de Israel. En el Nuevo Testamento, Jesús recibe este tratamiento por parte del ciego de Jericó (Marcos 10: 51) y de María Magdalena (Juan 20: 16). Parece ser que en este último pasaje, Juan le otorga el significado de "Maestro".

${ }^{11}$ Nótese el uso de "he orshe"como construcción lingüística indusiva.
} 
lo que subraya una vez más la tendencia de la autora hacia el lenguaje inclusivo.A continuación, la traducción de la Madre del Señor que ofrece Roberts le encomienda a la Magdalena que escriba las enseñanzas que le había transmitido su hijo tras la resurrección.

\section{CONCLUSIONES}

A lo largo de esta investigación creemos que hemos demostrado que actualmente la traducción reflejalos cambios sociales, políticos y culturales, como en el caso del feminismo.Asimismo, consideramos que hemos logrado aplicar la definición abarcadora de la traduccióncomo reescritura a un caso en concreto, la novela The Wild Girl ([1984] 2007). Esta obra constituye un fantástico ejemplo de esta nueva forma de entender la realidad como traducción personal y subjetiva del mundo, puesto que Roberts retraduce la realidad historiográfica, reinterpretándola bajo el marchamo del feminismo, para que se ajuste a su forma de ver el mundo y a su ética personal. Además, esperamos haber demostrado también que la traducción e interpretación de la realidad no son en absoluto neutras ni inocentes, sino que buscan un determinado skopos. Del mismo modo, parece que también ha quedado probado el concepto de la microfísica del poder, desarrollado por Foucault, y que parece de todo punto acertado para estudiar cómo la ideología y las desigualdades entre los hombres y las mujeres se filtran entre los mitos cristianos.

Por todo lo anterior, los traductores, en tanto que expertos del lenguaje, deberíamos asumirnuestra responsabilidad y tenermuy presente que el lenguaje es performativo y vive en tanto que hace. Por ello, a nuestro juicio, el traductor también debería poner su granito de arena para la mejora de la figura de la mujer en la sociedad.

\section{BIBLIOGRAFÍA}

Álvarez, R. y Vidal, M. C. A. (eds.) (1996). Translation, Subversion and Power. Cleveland, Multilingual Matters.

Álvarez, R. y Vidal, M. C. A. (1996). «Translating: A Political Act», en Álvarez, R. y Vidal, M. C. A. (eds.). Translation, Power, Subversion. Clevedon/Philadelphia/Adelaide, Multilingual Matters.

Baker, M. (2006). Translation and Conflict. Londres/Nueva York, Routledge.

Bassnett, S. ([1980] 2014). Translation Studies. Londres/Nueva York, Routledge.

- (1998): «The Translation Turn in Cultural Studies», en Bassnett, S. y Lefevere, A. (ed.): Constructing cultures: essays on Literary Translation. Clevedon: Multilingual Matters.

- (2011). Reflections on Translation. Bristol: Channel View Publications Ltd.

Bassnett, S. y Lefevere, A. (1990) (eds.): Translation, History and Culture. Londres: Pinter Publishers.

Bourdieu, P. (1991). Language and Symbolic Power. Cambridge (Massachusetts), Harvard University Press (traducción de G. Raymond y M. Adamson).

- (1992). «Deux impérialismes de l'universel», en Fauré, C.y Bishop, T. (eds) L'Amérique des Français. París, Éd. François Bourin.

- ([1998] 2015). La dominación masculina. Barcelona, editorial Anagrama (traducción de J. Jordá).

Brems, E. et al. (2014). The Known Unknowns of Translation Studies. Amsterdam, John Benjamins.

Duch, L. (1998). Mito, interpretación y cultura. Aproximación a la logomitica. Barcelona, Herder (traducción de F. Babí i Poca).

Eco, U. ([2003] 2008). Decir casi lo mismo. Experiencias de traducción. Barcelona, Lumen (traducción de Helena Lozano).

Foucault, M. ([1971] 1992). «Nietzsche, la genealogía, la historia», en Microfísica del poder. Madrid, La Piqueta (traducción de J. Varela y F. Álvarez-Uría).

- (1985). La microfísica del poder. Madrid, La Piqueta (traducción de J. Varela y F. Álvarez-Uría). 
Gauvin, L. (1989). Letters from an Other. Toronto, Women'sPress (traducción de S. de LotbinièreHarwood).

Gentzler, E. (2003). «Translation, Postcolonial Studies, and the Americas», EnterText, 2: 12-38.

Godard, B. (1990). «Theorizing Feminist Discourse/Translation», en Bassnett, S. y Lefevere, A. (1990): Translation, History and Culture. Londres, Cassell.

-Godard, B. (1995): «A Translator's Diary», en Simon, S. Culture in Transit: Translation and the Changing Identities of Quebec Literature. Montréal, Véhicule Press.

Godayol, P. (2005): «Frontera Spaces: Translation as/like a Woman», en Santaemilia, J. (ed.): Gender, Sex and Translation: The Manipulation of Identities. Manchester, St. Jerome.

Hermans, T. (ed.) (1985). The Manipulation of Literature. Studies in Literary Translation. Londres, Croom Helm.

Holmes, J. (1972). The Name and Nature of Translation Studies. Amsterdam, University of Amsterdam.

Johnston, D. (2013): «Professing Translation», Target, 25 (3): 365-384.

Lefevere, A. (1992): Translation, Rewriting and the Manipulation of Literary Fame. Londres/Nueva York, Routledge.

Lefevere, A. y Bassnett, S.([1990] 1995). «Introduction: Proust's Grandmother and The Thousand and One Nights: The 'Cultural Turn' in Translation Studies», en Lefevere, A. yBassnett, S. (eds.). Translation, History and Culture. Londres/Nueva York, Pinter Publishers.

Lotbinière-Harwood, S. (1995). «Geo-Graphics of Why», en Simon, S. (ed.): Culture in Transit: Translating the Literature of Quebec. Montréal, Véhicule Press.

Maier, C. (1985): «A Woman in Translation, Reflecting», Special Issue: Woman in Translation, Translation Review, 17: 4-8.

Martín Ruano, M. R. (2007). «El giro cultural de la traducción: perspectiva histórica, conflictos latentes y futuros retos», en Ortega Arjonilla, E. (ed.): El Giro Cultural de la Traducción. Frankfurt, Peter Lang.

Massardier-Kenney, F. (1997). «Towards a Redefinition of Feminist Translation Practice», The Translator, 3 (1): 55-69.

Munday, J. (2014). «Using Primary Sources to Produce a Microhistory of Translation and Translators: Theoretical and Methodological Concerns», The Translator, 20 (1): 64-80.

Roberts, M. ([1984] 2007). The Wild Girl. Londres, Vintage.

Simon, S. ([1996] 2010). Gender in Translation. Cultural Identity and the Politics of Transmission. Londres/Nueva York, Routledge.

Snell-Hornby, M. (2007). «Haz un diálogo y no la guerra: el estado actual de los Estudios de Traducción en el mundo académico», en Ortega Arjonilla, E. (ed.): El Giro Cultural de la Traducción. Frankfurt, Peter Lang.

Spender, D. (1992): Living by the Pen: Early British Women Writers. Londres/Nueva York, Teachers College Press.

Tymoczko, M. (2003). «Ideology and the Position of the Translator: In what Sense is a Translator 'Inbetween'?», en Calzada, M. (ed.). Apropos of Ideology. Translation Studies on Ideology-Ideologies in Translation Studies. Manchester, St. Jerome.

Tymoczko, M. (2007). Enlarging Translation, Empowering Translators. Manchester, St. Jerome.

Tymoczko, M. y Gentzler, E. (2002) (eds.). Translation and Power. Amherst y Boston, University of Massachussetts Press.

Vidal Claramonte, M. C. A. (2007), «Después del giro cultural de la traducción», en Ortega Arjonilla, E. (ed.). El Giro Cultural de la Traducción. Frankfurt, Peter Lang.

- (2010). Traducción y asimetría. Frankfurt, Peter Lang.

- (2015). Dile que le he escrito un blues. Madrid/Frankfurt, Iberoamericana Verurvert Verlag.

- (en prensa). «Powen», en Carbonell, O. y Harding, S. A. (eds.): Routledge Handbook of Translation and Culture.Londres/Nueva York, Routledge.

Von Flotow, L. (1991). «Feminist Translation: Contexts, Practices and Theories», TTR, 4 (2): 69-85.

Von Flotow, L. (1997). Translating and Gender: Translating in the Era of Feminism'. Manchester, St. Jerome. 
White, H. (1987). The Content of the Form. Narrative Discourse and Historical Representation. Baltimore/Londres, The Johns Hopkins University Press.

Wildeman, M. (1989). «Daring Deeds: Translation as a Lesbian Feminist Language Act», Tessera: La traduction au féminin. Translating Women, 6: 31-41. 